\title{
ДОПУСТИМОСТЬ СОВМЕСТНОЙ ФОРМЫ ЗАВЕЩАНИЯ В РОССИЙСКОМ ГРАЖДАНСКОМ ПРАВЕ
}

\begin{abstract}
Аннотация: Статья посвящена одной из актуальных на сегодняшний день проблем наследственного права: допустимости совместной формы завешания в российском гражданском праве. Анализ предмета исследования расширяет представления о форме совершения завещчаний в ичелом. Данный институт совместного завещания в России имеет перспективы развития. Научная полемика циивилистов ответ на данный вопрос оставляет открытым. Контрдоводом большинства правоведов является положительный опыт зарубежных стран в рассматриваемой сфере правоотношений, предоставляя тем самым больше возможностей для выполнения последней воли наследодателя. Особое внимание уделяется случаю, когда обычное завещание в описанной в статье ситуации не смогло бы соответствовать реальной воли супругов. Сравнительное исследование позволяет выявить правовые подходы и законодательное регулирование, которые должны пройти тмательный процесс проработки. Важно учесть при этом баланс интересов умершего и пережившего супруга. Автор приходит к выводу о необходимости совершенствования отечественного законодательства о наследовании.
\end{abstract}

Ключевые слова: совместное завещание, завешание, наследование, составление завешания, наследник, наследодатель, совершение завещчания, завещяание супругов, недействительность завещчания, наследственное право

B современной юридической литературе вопрос о допустимости совместной формы завещания в российском гражданском праве является дискуссионным.

Законодательство Российской Федерации не предусматривает возможности составления совместного завещания. Часть 4 статьи 1118 Гражданского Кодекса Российской Федерации гласит о запрете на составление завещания двумя или более гражданами.

В дореволюционной и советской юридической доктрине ряд ученых не разделяют введения совместной формы завещания и полностью солидарны с позицией отечественного законодателя о недопустимости выражения в одном документе воли двух и более лиц, указывая именно на то, что завещание - это такая личная сделка, которая может содержать волю только одного лица.

Так В.И. Серебровский обращал внимание на то обстоятельство, что не могут, например, отец и мать одним завещанием завещать свое общее имущество, нажитое в браке, своим детям. Но каждый из них может в отдельно составленном завещании распорядиться принадлежащей ему долей в общем имуществе, равно как и лично ему принадлежащим (раздельным) имуществом ${ }^{1}$. Идентичную

${ }^{1}$ Серебровский, В.И. Очерки советского наследственного права / В.И. Серебровский - Академия наук СССР, 1953. - С.116. позицию поддерживает Я.В. Абрамов, замечая, что завещание должно составляться каждым завещателем отдельно; два лица в одном завещании не могут изъявлять свою волю ${ }^{2}$.

По мнению К.П. Победоносцева, человек не распорядился решительно при своей жизни, в том распоряжается на случай смерти: дает из своего после себя, что хочет и кому хочет свободно, т.е. оставляя волю свою при себе, пока жив, и не связывая ее ни с чьей иной волей. По духу нашего закона договорное, связующее начало противно сущности завещания, предполагающего единство воли, и потому всякий волен отменить свое завещание или определить свою волю иным образом. Эта свобода может принадлежать только единой воле, и потому закон наш не допускает совместных завещаний, в коих два (или более) лица изъявляют свою волю совокупно 3 .

При этом, как писал А. Любавский, неудобно допустить совокупные завещания потому, что они сделались бы

\footnotetext{
${ }^{2}$ Абрамов Я. В. Духовные завещания: как их составлять, изменять, отменять, представлять к утверждению и оспаривать / составил Я. В. Абрамов. - 2-е изд. - С.-Петербург: Тип. М. Меркушева, 1900. - C.21.

${ }^{3}$ Победоносиев К.П. Курс гражданского права. Часть вторая: Права семейственные, наследственные и завещательные. - М.: «Статус», 2003. - C.422.
} 
договорами о наследстве и получили бы характер обоюдных обязательств, основанных на взаимном соглашении. Завещание должно быть результатом воли лишь одного завещателя. Кроме того следует избегать, чтобы акты, не имеющие между собой внутренней связи, имели между собой связь материальную. Неудобство этого заключается в том, акт может в одно и то же время понадобиться обеим сторонам, что он, находясь в руках одной из них, может быть ею уничтожен, от чего пострадают интересы другой стороны ${ }^{4}$.

Даёт однозначно отрицательный ответ на поставленный вопрос А.А. Подопригора: «При завещании нет совпадающего двустороннего и единовременного волеизъявления, которое требуется при заключении договора. Нет, и не может быть, поскольку завещателя уже нет в живых ${ }^{5}$ ».

На указанную проблему обратил свое внимание Н.Н. Товстолес, который приводит доводы в пользу совместного завещания. В ходе рассуждений он пришел к выводу о том, что при общем составлении завещания, оба завещателя могут распоряжаться в пользу какого-либо третьего лица, так что воля одного из них независима от распоряжения другого; в таком случае, казалось бы, свобода воли завещателя отменить свое завещательное распоряжение ничуть не связана волею другого и не терпит никакого стеснения со стороны последнего 6 .

В настоящее время, большинство правоведов считают введение в российское законодательство нормы, допускающей совместное завещание, целесообразным.

О.Е. Блинков считает, что препятствий для имплементации данных институтов современного зарубежного гражданского права в российский наследственный закон нет ${ }^{7}$.

Представителями нотариального сообщества формируется пакет предложений, как защитить последнюю волю человека от подделок. Одной из важных идей стало предложение ввести совместное завещание, которое предусматривает совместную договоренность супругов о судьбе принадлежащего имущества, когда смерть разлучит их. У каждого в семье есть что-то личное: у одного счета в банках, у другого квартира. Формально человек волен распоряжаться своим добром, как хочет, даже если

\footnotetext{
${ }^{4}$ Любавский А. Об упрощении внешней формы завещаний. - СПб.: Типолитография Л. Ландвигера, 1865. - С.240-241 .

${ }^{5}$ Подопригора А.А. Основы римского гражданского права: Учеб. пособие для студентов юрид. вузов и факультетов, - 2-е изд., перераб. - К.: Вентури, 1995. - С.272.

${ }^{6}$ Товстолес Н. Н. Законодательство общее и местное о духовных завещаниях в связи с судебною практикою и литературою вопроса / Н. Н. Товстолес. - СПб.: Изд. Книжного магазина юрид. литературы, 1900. - С.77.

${ }^{7}$ Блинков, О. Е. Многосторонние завещания в наследственном праве зарубежных стран /О. Е. Блинков.//Современное право. -
} 2008. - № 11. - C. 120. другой половинке это не нравится. Скоро и мы придем к такой свободе частной собственности. Люди не всегда горят желанием разделить с любимой женой, скажем, купленную еще бабушкой дачу. В таких случаях совместное завещание позволяет супругам прояснить имущественные взаимоотношения после смерти одного из них. Любящие сердца садятся за стол и прописывают, кому что достанется на этом свете, если другой окажется в мире ином. Составленная бумага может наложить на человека и некоторые обязательства, например, не продавать машину, так как она отписана после смерти жене, не пропивать имение, не проигрывать в карты гараж ${ }^{8}$.

Данное предложение о введении совместной формы завещания в российском законодательстве эксперты Федеральной нотариальной палаты России привезли с международной конференции по наследственному праву, проходившей в немецком городе Любек, организованной Российско-германским юридическим институтом при Кильском университете.

Между тем, данная форма завещания на сегодняшний день является распространенной в наследственном праве европейских стран (Англия, Австрия, Германия), а так же официально закреплена в гражданском законодательстве некоторых стран СНГ (Азербайджана, Грузии, Туркменистана, Эстонии, Литвы) в которых возможны завещательные распоряжения нескольких лиц.

Наравне с Российской Федерацией законодательство Франции, а так же стран бывшего СССР: Киргизии, Молдовы, Таджикистана, Казахстана, Беларуси, Узбекистана, на сегодняшний день исключает совместное завещание. Более того оно прямо запрещает данную форму завещания.

Новацией стало закрепление совместных завещаний в законодательстве Украины. Гражданский кодекс (ГК) Украины 2003 года предусматривает возможность супругов составлять совместное завещание. Ранее в ГК УССР наследодатель определялся, как и в действующем законодательстве Российской Федерации, исключительно отдельным гражданином.

Стоит обратить внимание на статью 1243 Гражданского кодекса Украины, которой установлено право супругов на совместное завещание. Так, супруги могут оформить совместное завещание относительно имущества, которое принадлежит им на праве общей совместной собственности. При составлении совместного завещания доля в праве общей совместной собственности после смерти одного из супругов переходит к другому супругу, который его пережил. В случае смерти последнего право на наследование имеют лица, определенные супругами в завещании. При жизни жены и мужа

\footnotetext{
${ }^{8}$ Куликов В. Смертельный случай // Российская газета. 2011. 28 июня.
} 
DOI: 10.7256/1811-9018.2013.7.8888

При цитировании этой статьи сноска на dоі обязательна

\section{Право и политика 7 (163) • 2013}

каждый из них имеет право отказаться от совместного завещания, и такой отказ подлежит нотариальному удостоверению. В случае смерти одного из супругов нотариус налагает запрет отчуждения имущества, указанного в завещании супругов (ст.1243 ГК Украины от 16 января 2003 года.). Безусловно, введение данного новшества сделало более гибким институт наследственного права Украины.

В Гражданском кодексе Грузии статья 1347 позволяет супругам составить совместное завещание о взаимном наследовании. При этом, совместное завещание может быть отменено по требованию одного из супругов, но еще при жизни обоих супругов. Похожие правила содержат статья 1164 Гражданского кодекса Республики Туркменистан и статья 1169 Гражданского кодекса Азербайджанской республики.

Следует отметить, что в Эстонии не урегулированы наследственные правоотношения Гражданским кодексом. В 1996 году был принят специализированный Закон «О наследовании», более детально регламентирующий вопросы наследования, а именно содержит положения о взаимном завещании супругов. В частности, статья 87 данного закона дает определение взаимного завещания супругов. Оно определяется как совместное завещание, в котором супруги взаимно назначают себя наследниками один после другого, при этом действительность назначения наследником одного из супругов зависит от действительности назначения наследником другого супруга.

В Германии положения касательно совместного завещания супругов содержатся в Главе 8 Германского гражданского уложения (ГГУ). Совместное завещание - это, как правило, единый документ, который состоит из двух завещаний супругов (возможность составлять совместные завещания предоставлена Германским гражданским уложением только супругам), где каждый супруг распоряжается своим имуществом в одностороннем порядке. Однако оба завещания образуют совместное завещание, когда существует явно выращенная воля наследодателей об установлении единого порядка9

Оно может быть составлено собственноручно одним из супругов, а другим просто подписано это совместное распоряжение.

Если супруги по общему завещанию, которым они назначили друг друга наследниками, распорядились, чтобы после смерти пережившего супруга их общее наследство перешло к третьему лицу, то третье лицо будет считаться наследником, назначенным в отношении всего наследства супруга, умершего последним.

\footnotetext{
${ }^{9}$ Ворониов В.М., Сигов А.С. О понятии совместного завещания по гражданскому праву Германии.// ВЕСТНИК АССОЦИАЦИИ ВУЗОВ ТУРИЗМА И СЕРВИСА .- 2010.- № 1. С. 49-50.
}

Общее завещание супругов, в котором один супруг назначает наследником другого, будет являться недействительным, если брак признан недействительным или расторгнут до смерти наследодателя.

При жизни одного супруга другой не может отменить свое прежнее распоряжение в одностороннем порядке новым распоряжением на случай смерти. Отмена распоряжений супругов в результате развода производится при жизни супругов путем подачи заявления об отказе от договора, это заявление должно быть нотариально удостоверено ${ }^{10}$.

Вышесказанное позволяет сделать вывод, что по законодательству Российской Федерации нельзя совершить завещание двумя (например, супругами) или более лицами. С нашей точки зрения, данная форма завещания имеет место быть в будущем. Было бы целесообразно, на наш взгляд, учитывать зарубежный опыт при дальнейшем совершенствовании отечественного законодательства. Прежде всего, введение института совместного завещания как единого документа с завещательными инструкциями мужа и жены в законодательстве Российской Федерации приведет к более эффективной реализации прав граждан. Практика применения института совместного завещания зарубежных стран уже сформировала положительный опыт в данной сфере правоотношений и достаточно убедительно доказывает, что законодательство Российской Федерации нуждается в совершенствовании. Данный институт права основан, прежде всего, на балансе интересов умершего и пережившего супруга. В нём также сосредоточены гарантии соблюдения воли покойного и в то же время предоставлены возможности пережившему супругу в случае необходимости изменить совместное завещание супругов. Необходимо предоставить наследодателю более широкие возможности по выбору того или иного вида завещательных распоряжений, и тем самым, гарантировать выполнение последней воли завещателя. А это станет возможно только при наличии четкой правовой регламентации новых положений наследственного права России.

\section{Библиография:}

1. Абрамов Я. В. Духовные завещания: как их составлять, изменять, отменять, представлять к утверждению и оспаривать / составил Я. В. Абрамов.-2-е изд.-С.-Петербург: Тип. М. Меркушева, 1900.-64 с.

2. Блинков, О. Е. Многосторонние завещания в наследственном праве зарубежных стран /О. Е. Блинков.// Современное право.-2008.-№ 11.-С. 117 - 120.

\footnotetext{
${ }^{10}$ URL: http:// bundesrecht.juris.de/ bgb/ index.html.
} 
DOI: $10.7256 / 1811-9018.2013 .7 .8888$

При цитировании этой статьи сноска на dоі обязательна

Трансформация правовых и политических систем

3. Воронцов В.М., Сигов А.С. О понятии совместного завещания по гражданскому праву Германии.// ВЕСТНИК АССОЦИАЦИИ ВУЗОВ ТУРИЗМА И СЕРВИСА.-2010.-№ 1. С. 49-53.

4. Куликов В. Смертельный случай // Российская газета. 2011. 28 июня.

5. Любавский А. Об упрощении внешней формы завещаний.-СПб.: Типолитография Л. Ландвигера, 1865.-286 c.

6. Победоносцев К.П. Курс гражданского права. Часть вторая: Права семейственные, наследственные и завещательные.-М.: “Статус”, 2003.-639 с.

7. Подопригора А.А. Основы римского гражданского права: Учеб. пособие для студентов юрид. вузов и факультетов, - 2-е изд., перераб. - К.: Вентури, 1995. - 288 с.

8. Серебровский, В.И. Очерки советского наследственного права / В.И. Серебровский - Академия наук CCCP, 1953. - 240 c.

9. Товстолес Н. Н. Законодательство общее и местное о духовных завещаниях в связи с судебною практикою и литературою вопроса / Н. Н. Товстолес. - СПб.: Изд. Книжного магазина юрид. литературы, 1900.-119 с.

10. URL: http:// bundesrecht.juris.de/ bgb/ index.html.

\section{References (transliteration):}

1. Abramov Ya. V. Duhovnye zaveschaniya: kak ih sostavlyat', izmenyat', otmenyat', predstav- lyat' k utverzhdeniyu i osparivat' / sostavil Ya. V. Abramov.-2-e izd.-S.-Peterburg: Tip. M. Merkusheva, 1900.-64 s.

2. Blinkov, O. E. Mnogostoronnie zaveschaniya v nasledstvennom prave zarubezhnyh stran /O. E. Blinkov.//Sovremennoe pravo.-2008.-№ 11.-S. 117 - 120.

3. Voroncov V.M., Sigov A.S. O ponyatii sovmestnogo zaveschaniya po grazhdanskomu pravu Germanii.// VESTNIK ASSOCIACII VUZOV TURIZMA I SERVISA.-2010.-№ 1. S. 49-53.

4. Kulikov V. Smertel'nyy sluchay // Rossiyskaya gazeta. 2011. 28 iyunya.

5. Lyubavskiy A. Ob uproschenii vneshney formy zaveschaniy.-SPb.: Tipolitografiya L. Landvigera, 1865.-286 s.

6. Pobedonoscev K.P. Kurs grazhdanskogo prava. Chast' vtoraya: Prava semeystvennye, nasledstvennye i zaveschatel'nye.-M.: «Status», 2003.-639 s.

7. Podoprigora A.A. Osnovy rimskogo grazhdanskogo prava: Ucheb. posobie dlya studentov yurid. vuzov i fakul'tetov, - 2-e izd., pererab. - K.: Venturi, 1995. - $288 \mathrm{~s}$.

8. Serebrovskiy, V.I. Ocherki sovetskogo nasledstvennogo prava / V.I. Serebrovskiy - Akademiya nauk SSSR, 1953. - $240 \mathrm{~s}$.

9. Tovstoles N. N. Zakonodatel'stvo obschee i mestnoe o duhovnyh zaveschaniyah v svyazi s sudebnoyu praktikoyu i literaturoyu voprosa / N. N. Tovstoles. — SPb.: Izd. Knizhnogo magazina yurid. literatury, 1900.-119 s. 